\title{
THE EPINICIAN SPEAKER AS PRECEPTOR:
}

\section{PINDAR'S PYTHLAN 2.72-96}

J.R. Louw, University of the North

Text

yévol', oîos É $\sigma \sigma i ̀ ~ \mu \alpha \theta \dot{\omega} v$.

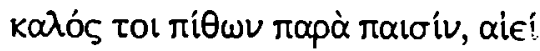

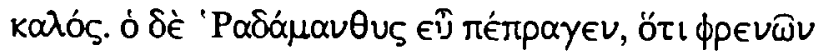

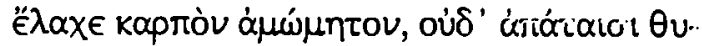

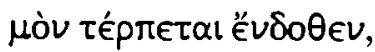

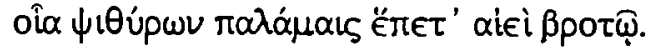

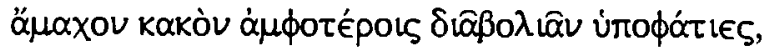

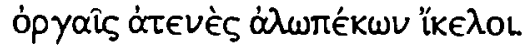

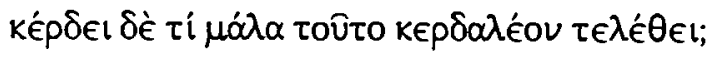

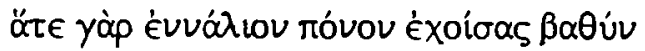

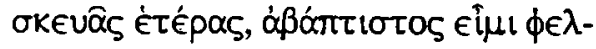

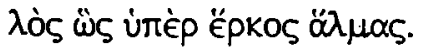

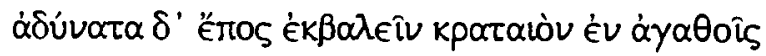

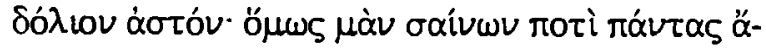

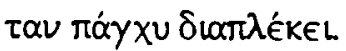

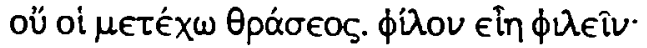

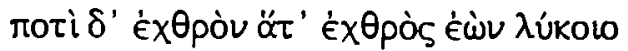

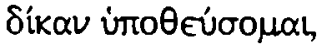

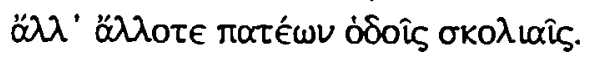

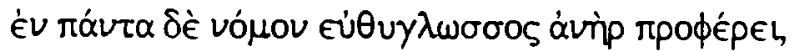

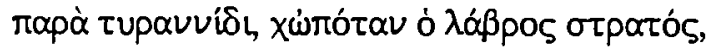

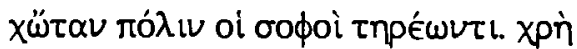

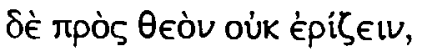

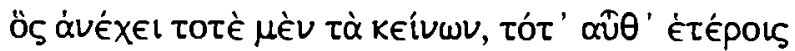

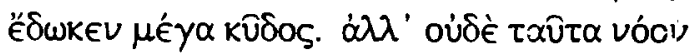

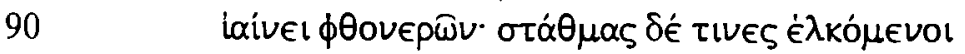

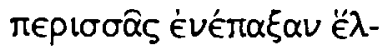

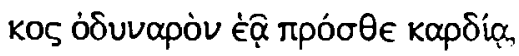




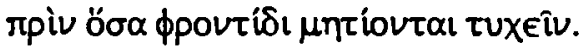

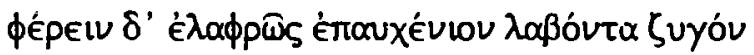

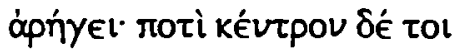

95

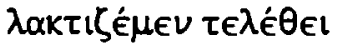

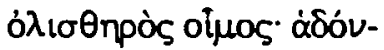

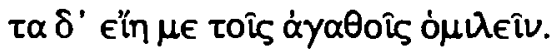

\section{Translation}

72 "Be what manner of man you have learned you are.

Pretty indeed is the ape to children, always

Pretty. But Rhadamanthys has prospered, becanse he has gained

A blameless harvest of his mind, and does not delight in deceit

75 Which, by the cunning of whisperers, always pursues a man.

An irresistible evil to both are the purveyors of slander,

Utterly like foxes in their disposition.

But how then does subterfuge profit the fox?

Likewise the rest of the tackle labours in the depth

80 Of the sea, I am like a cork, unsubmerged above the swell of the sea.

But the deceitful citizen fails to voice an effective word

Among the noble: indeed, by fawning in the same way on all,

he weaves his delusion completely.

I do not share his insolence. May it be to love my friend:

But I, being just like the enemy, shall secretly attack the enemy in the wolf's way,

85 But treading at another time my winding paths.

In each state the straightforward man excels,

Whether in a tyranny, or whensoever the noisy commons,

Or the wise, watch over the city. Man

should not quarrel with god,

Who exalts then one group, then again to others

gives great honour. But not even glory

90 Cheers the envious' mind: some, straining the measuring line

To the limit stick

a painful wound to their heart,

Before they can attain what they devise in their mind.

It is better to bear lightly the yoke acquired

On one's neck: but to kick

95 against the pricks is

A slippery road. May it be mine

to please, and to consort with noble men!"

The aim of this paper is twofold: (a) to employ some insights gained from literary theory on the speaker in a text, and to relate these to a particular controversial passage in Pindar;

(b) to present a possible interpretation of the passage cited. 
The first person in Pindar's victory odes has long been regarded within the parameters of the Biographic Method, with its pursuit of Romanticism, as the personal - often aggravated - expression of the historic poet Pindar. This has led, inevitably, to a situation where the literary merit of the odes was overlooked in favour of a search to reconstruct the life and times of Findar.

The investigation into the nature and function of literary personae has also been a preoccupation of Structuralist poetics, and in particular that of narratology. The first person in a text, within these circles, is viewed as one possible manifestation 1 of the speaker, 2 viz. the narrating instance created by the author, which generates and produces a text (Genette 1980:212-215). The speaker should never be identified with the historic author, even though he or she might have the appearance of the author's "image" (Bakhtin $1984: 90-92) \cdot{ }^{3}$

In the past most stidies on the speaker have centred around the question, "who is the iatended referent?",4 and not, "what is his function?" It is only recently that this latter question has arisen. Based on tire sneech acts, and acts of the epinician speaker (henceforth the E-speaker) Nancy Rubin ascribes ceriain roles, sich as celeb:ator, commemorator, iniarcessor and others to this speaker (1984:377-397).5 Therefore, in Olympian 6.1-3, the communui' speaker - in the first person plural - reveals himself as the composer of a victory ode in commemoration of Agesias' chariot victory. In 6.85-87 he again refers to

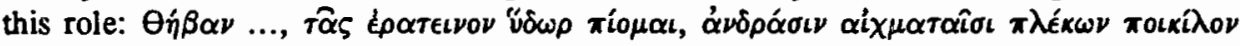
Ürov ("Thebes ..., whose lovely water I drink, plaiting the multisonous song for

1 First person, second person and third person narration presuppose narrating instance, which can be identified as an "I". First person narration differs from the other voices only insofar as that in first person narration the " $I$ " in the text coincides with the position of the speaker. We know intuitively that the speaker in the sentence, "I see Peter walking down the street" is an "I". Therefore: "(I say) I see Peter walking down the street". For the different signs of the "I" in a text, see Prince 1976.

2 Sometimes also called the narrator or enunciator.

3 Modern literary theory has, generally speaking, little room for the author when it comes to interpreting texts. Observe the title of one of Roland Barthes most famous essays in MusicImage-Tex, "The Death of the Author" (1977).

4 The Biographic Method views the poet as speaking in propria persona; more recent studies emphasise a plurality of referents. Fraienkel (1975:475, note 12), for example, contends that the "I" may refer to the victor (Isthmian 7.49ff.), the poet (Pyzhian 7.18), the chorus (Pythian 5.75ff.) or an Impersonal first person which may pertain to every hearer/reader (Pyrhian 11.50ff.).

5 Both her indebtedness to, and differing with Propp's treatment of character analysis in Russian folk-tales are conspicuous; whereas Propp (1968) identifies a limited number of actantial roles, a proliferation of speaker roles sbound in Rubin.

6 Here the speaker compares his role as composer to that of architects building a palace. 
spearmen"). 7 The present paper, therefore, will focus on yet another socially determined role, viz. the speaker as preceptor in Pindar's Pythian 2.72-97.

Outwardly Pythian 2 displays the same thematic development as a Beethoven sonata: the exposition (vv.1-24) highlights the main theme of the ode, viz. the success of Hieron in the chariot race (vv.3-4); the development (vv.21-52) amplifies and contrasts Hieron's success by relating the mythical tale of Ixion, the supreme example of the brevity and frailty of human prosperity. The recapitulation (vv.52-96) again takes up the main theme, notably the laud due to the victor, but always against the setting of the development.8

The recapitulation, in turn, may be subdivided into two sections: the first section (vv.5271; see footnote 8) features the laud of the victor, while the second (vv.72-96) focuses on the actions of the victor. Controversy exists with regard to the question whether verses 72 96 are even addressed to the victor; Bowra (1937:24) views these verses as a personal monologue, by the historical poet, directed at certain defamators9 at Hieron's court. Gildersleeve (1885:254) regards verses $72-96$ as essentially an "afterpiece", structurally

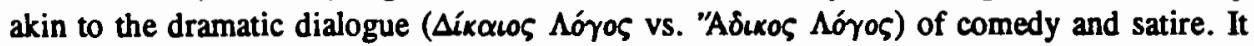
is plain, however, that the narration of verses $72-96$ takes place within the spatial and temporal confines of the narrator, already introduced at the start of the recapitulation as an

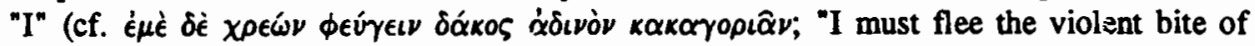
evil-speaking"). 10 The fact that the ode is dedicated to Hieron on the occasion of his chariot victory at Pythia (vv.3-8), and that the issues arising from the ode should therefore reflect the primary intent and occasion, should preclude any attempt to equate the textual "I" with the historical poet Pindar.11

7 It should be observed that these roles are often expressions of the speaker's $\chi \rho \in$ éo (social duty) towards his patron. This social duty arises both from the ancient conception that laudable deeds should be duly compensated, and the fact that commissioned poets such as Pindar were handsomely paid, by their patrons, for a victory ode!

8 This is expressed in three subsections: verses 52-56: the necessity to praise; verses 57-67: the praise of the victor, and verses 67-71: accepting the praise.

9 Both Woodbury (1945:11-30) and Burton (1962:111-134) are in agreement with Bowra on this issue, although Burton considers the last triad as addressing ordinary citizens (cf. $\pi \alpha \rho \dot{\alpha}$ $\left.\pi \alpha \sigma^{\prime} \nu, v .72\right)$, or so-called "agents provocateurs" at the court of Hieron.

10 This verse is riddled with interpretative questions: to whom does the "I" refer, to someone indefinite, or to the poet?; does the verse allude to any historical events? Bowra (1937:24) identifies the $k \alpha \kappa \alpha \gamma o \rho<\alpha i$ with the pernicious activities of slanderers at the court of Hieron, labouring to discredit the poet. Grimm (1962:1-9), following the lead of Bowra, even attempts to interpret $\delta \dot{\alpha} x \circ 5$ as a metaphor for Bacchylides, who was to have joined others in slandering Pindar. In verse 52, however, the narrator reaffirms his role as commemorator by reiterating his social obligation ( $\chi \rho \in \delta \zeta \zeta)$ to praise the victor. The evil-speaker is the negative counterpart of the commemorator, and prefigures Archilochus' invective poetry (vv.54-55).

11 Sometimes the "I" approximates the historical poet in such an embarrassing way that it almost becomes the "image" of the poet. But as Bakhtin (1984:52) bas rightly pointed out, the image is always a product (something produced and manipulated by the poet) and never a producer (the author who writes down a literary work of art). 
In verse 72 , the narrator addresses the victor now for the fifth time: the other occurrences

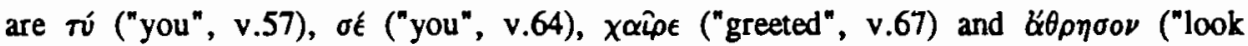
upon!", v.70). The fact that all these apostrophes bear direct reference to the main theme, viz. the praise of the victor, should draw the reader's attention to the fact that the theme, albeit from a different angle, is introduced once more.

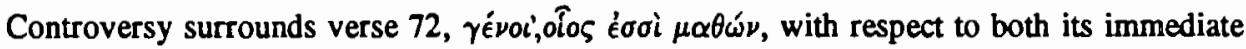
constituents, meaning and translation. Thummer (1972:296) has shown, to worsen matters even further, that agreement on the immediate constituents does not necessarily lead to assent in meaning.

Depending on one's interpretation, the immediate constituents may be determined in three different ways:

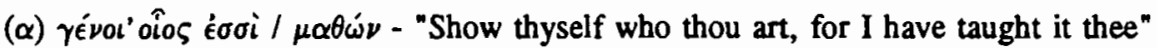
(Gildersleeve 1885:264).

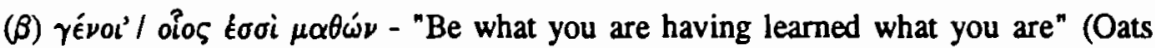
1963: 382); "learn what you are and become such" (Mullen 1982:131).

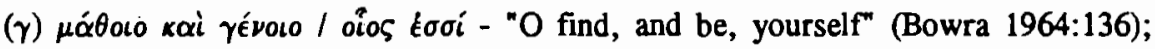
"learn and become what you are" (Lefkowitz 1976:25-26). So too, Carey (1981:50). The weakness of this proposal is that it accords equal importance to yévolo and

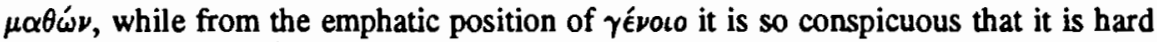
to overlook. Equally evident is the loosely connected $\mu \alpha \theta \dot{\omega} \nu$, apparently without an object.

This troublesome verse, however, cannot be adequately discussed without observing the context in which it operates. Earlier, in verse 56, the narrator has said the following: to

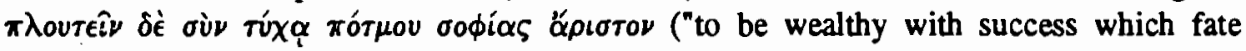
gives, is the finest wisdom").12 The narrator emphasises not the mere possession of

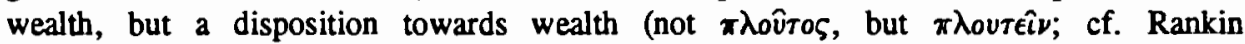

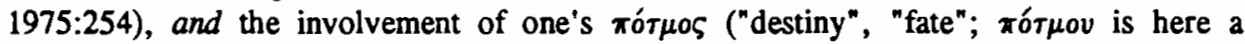
genitive of source). Clearly, the gnome looks backwards and forwards: backwards, because it furnishes an appropriate conclusion to the Ixion myth; Ixion's $\gamma \lambda u x \dot{\nu} \nu$ Biotov ("sweet life", v.26) was clearly not his destiny, because through his own li $\beta \rho \iota \zeta$ ("hybris") he

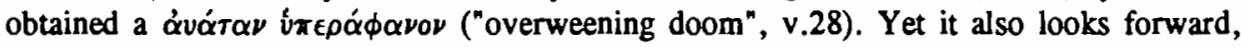
because, as the narrator painstakingly points out in verses $57-67$, destiny has indeed cast its eyes caringly on Hieron. This now leads the narrator to request Hieron himself to gaze favourably upon the present ode as a fair reward (vv.67-71).

Verse 72 now links up with the whole of verses 56-71; in particular the narrator invites the victor to show 13 himself to be the manner of man $(=\hat{o l o s} \dot{\epsilon} \sigma \sigma i) 14$ he has learned he is. The lessons Hieron has learned thus refer to his high (political) position and status as a stouthearted soldier clearly emphasised in verses 56-67 ( $\mu \alpha \theta \dot{\omega} \nu$ here connotes "now you have learned"). Clearly, the line is a reaffirmation of the old exhortation, $\gamma \nu \hat{\omega} \theta_{\iota} \sigma \alpha v$ ró$^{\prime}$ ("know yourself").

12 The translation rests upon Gerber's interpretation (1960:105). For an exhaustive and cogent treatment, yet offering a different conclusion, see Most 1985:47-71.

13 Observe the use of the aorist optative; the present situation requires a very specific response from the victor (Most 1985:103). 
An analysis of the context therefore seems to favour an interpretation along the lines mentioned in $(\beta)$. In the ensuing verses the narrator will, from his own perspective, instruct the victor in what kind of response (cf. révoLo, v.72) is required. The preceptive intent of the narrator is already conspicuous in verse 72: earlier, rather ominously, the narrator has said of Ixion: "̌e $\mu \alpha \theta \epsilon \delta \dot{\epsilon} \sigma \alpha \phi \hat{\epsilon} \varsigma$ ("he learned clearly", v.25), and then continues to describe his ruin. Now, he refers to Hieron who has learned ( $\mu \alpha \theta \dot{\omega} v)$.

The narrator's exhortation of the victor towards self-knowledge is reinforced by two examples, one negative (vv.72-73), the other positive (vv.73-74). The introduction of Rhadamanthys (vv.73-74) has a direct relation to the Ixion myth and the victor Hieron: unlike Ixion who has found his own "sweet life" (v.26) to be short-lived, Rhadamanthys receives prosperity without blame ( $\phi \rho \epsilon \nu \hat{\omega} \nu . . . \kappa \alpha \rho \pi \grave{\nu} \nu \alpha \mu \omega \dot{\mu} \mu \eta \tau o \nu, ~ v .74)$. But, just as Hieron has learned about himself, Rhadamanthys is above reproach of deception. Ixion, on

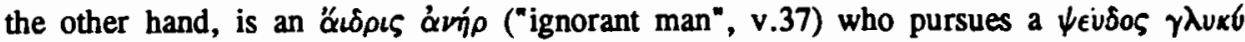
("sweet lie") thinking that he can escape the wrath of Zeus in his attempt to seduce Hera.

The image of the ape (vv.73-74) has elicited much commentary. The ape is often appreciated as an allegorical metaphor, because it apparently exposes some inherent defect 15 in men. The true contrast, however, is not between the ape and Rhadamanthys, but rather between the children and Rhadamanthys (Carey 1981:54). The children, who find the ape amusing ( $\kappa \alpha \lambda o \varsigma)$, are utterly deceived in the end. Now compare Ixion, deceived by

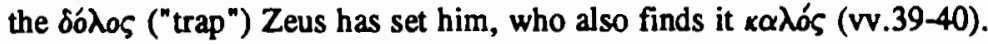

The following unit, verses $76-80$, links up and expands the saying of the evil-speakers in verse 52-53 ("I must flee the violent bite of evil-speaking"): "an irresistible evil are purveyors of slander to both, utterly like foxes in their disposition". The evil-speakers now have become $\delta\llcorner\alpha \beta 0 \lambda \iota \alpha \hat{\nu} v \pi 0 \phi \alpha ́ \alpha \iota \epsilon \varsigma$ ("purveyors of slander"). What is beginning to emerge is a complete contrast between the Honest Man and the Slanderer who defames and deceives. The narrator, Rhadamanthys, and Hieron by implication (observe the narrator's comment in verse 57,16 following on verse 56), are the Honest Man; Ixion and the gullible children are the Slanderer. Observe also the different modus operandi of the narrator versus that of the slanderer: while his praise of the victor is open and unreserved (Bou $\alpha \alpha i$

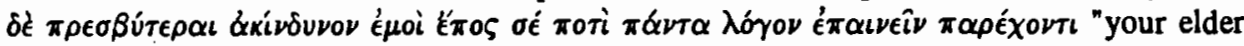
councils grant me a fearless word to praise you with regard to every statement", v.66), the slanderer engages himself in whispering (the slanderer is a $\psi\llcorner\theta$ í $\rho \circ 5, v .75$ ), secrecyl7 and futile cunning. 18 The narrator and his allies, however, stand aloof above the slyness,

15 Bowra regards the ape as an image for the imitator; the children, delighted by the ape's antics, refer therefore to those admirers of Bacchylides at Hieron's court (1937:9-10). For Burton the ape is the mischief-maker, the deceiver; the children are then Pindar's slanderers (1962:126127).

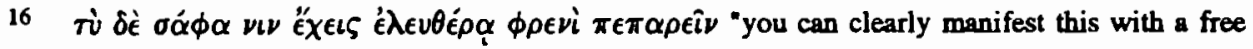
mind".

17 The preposition $\dot{\pi} 0-$ in $u \pi 0 \phi \alpha \dot{T} \iota \epsilon \zeta$ most likely denotes concealment (Carey 1981:56). See also Most's discussion of the contrast between openness and concealment (1985:109-111).

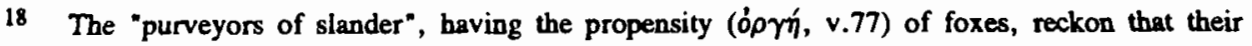

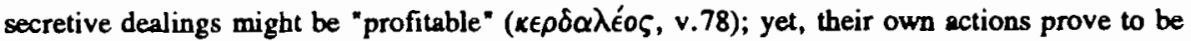

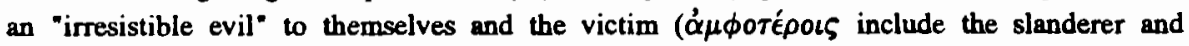

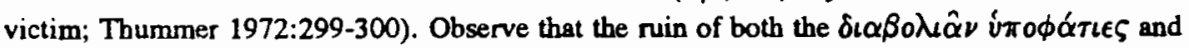
Archilochus ( $v$.54-56) is self-inflicted; Archilochus, "battening on his own hate vented in

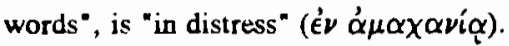




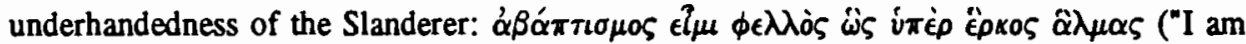
unsubmerged like a cork above the swell of the sea").

In the next unit, verses $81-88$, the narrator advises the victor on the appropriate action to be taken in the political sphere. That we have indeed moved into the discourse of politics is

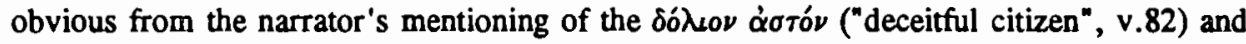
the different forms of government (vv.86-88).19 The true contrast here is between the

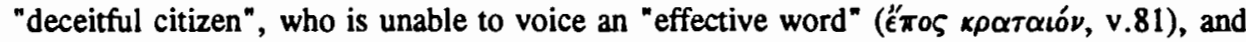
the ungullible $\alpha \gamma \alpha \theta 0$ í ("the noble", v.81).20 The "deceitful citizen", unable to impress the "noble", continues on his way of self-deception: "indeed, he weaves his delusion together by fawning in the same way upon all".21

The fitting response of the "noble" towards the "deceitful citizan" is phrased ithin the parameters of archaic morality (vv.83-85): as Adkins (1960:31ff., 46ff., 166ff.) rightly points out, archaic morality, in deciding ethical behaviour, does not take into account the intention, but rather the end result, of such behaviour. The deceiver is not at fault because he is intent on deceiving, but because he acts in the same way in all circumstances. The $\alpha \gamma \alpha \theta o ́ s$, on the other hand, may use deceptive means and will still be considered as $\dot{\alpha} \gamma \alpha \theta \delta$ s, if he gives due consideration to the result of his action.

Indeed, because the narrator senses that the exigencies of the present situation cail for action that befits his social duty towards his patron, he openly gratifies the claim: "may it be to love my friend: but the enemy, being just like the enemy, I shall secretly attack in the way of a wolf, but at another time treading my winding paths". The narrator's use of the wolf image does not imply that he has lost his head, as Farnell says (1932:131), but that he

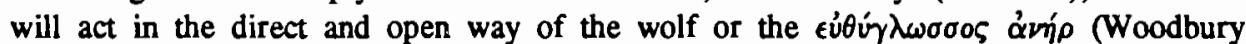
1945:25) in order to fulfil his xpєós. The slanderer and the deceitful citizen, of course, not realising what is expected of them, continue to weave their delusion complete (v.82).

Previously, the narrator instructed the victor on how to act in very specific spheres of life; in the last subsection, verses 88-96, the narrator describes man's place in the cosmos controlled by god. The universal validity of the narrator's warning in verse $88 \mathrm{~b}(\alpha \rho \dot{\eta} \delta \dot{\epsilon}$ $\pi \rho \grave{\zeta} \theta \epsilon \dot{\partial} \nu$ oík $\epsilon \rho i \zeta \epsilon \epsilon \nu$ "man must not quarrel against god") confirms now that the purveyors of slander (v.76) and deceitful citizen were all negative examples of people denying god as the ruler of destinies. The notion god that rules the destiny of man is not only central to the oeuvre of Pindar, but is also built into the structure of Pythian 2.22 Acceptance of this notion (i.e. god as ruler of destinies) should usually "cheer the mind" (vóov laiveıv, v.90),

19 Bowra (1964:137) contends that these verses bear witness to a Pindaric preference for a specific form of government, viz. "the aristocratic society of the 'wise', because Pindar doscribes

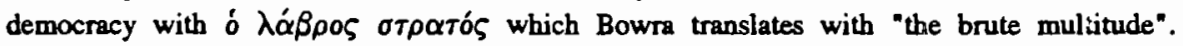
$\lambda \alpha \beta_{\beta} \rho \varsigma$ is more likely to refer to the din in the assembly, and, therefore, does not suggest any disparagement of democracy as such (Lloyd-Jones 1973:112, n.17, but contra Carey 1981:60).

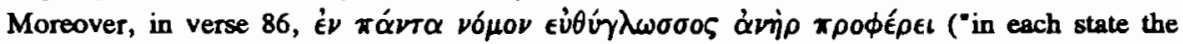
straightforward man excels") the narrator specifically precludes any interpretation inviting contempt for democracy.

20 We should refrain from taking the narrow view that the "noble" only refer to the aristocracy of Pindar's time. Here the term merely refers to those individuals who oppose the devious ways of the Slanderer.

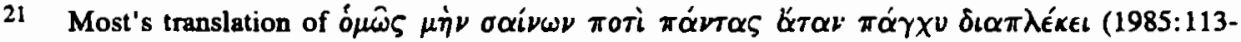
114).

For a detailed discussion of Pythian 2's structure, see Louw (1985:24-27). 
but (observe the contrastive $\alpha \lambda \lambda \alpha \dot{\alpha}, v .89$ ) not that of the $\phi \theta 0 v \in \rho o$ ó ("the envious", v.90). Because they strive for what is beyond their state, they destroy themselves (vv.91-92).23

Verses 92-94a recall the gist of verse 72: man must accept his róx in life. Anything else amounts to rebellion against god's rule. The narrator now concludes the victory ode with a prayer: "may it be mine to consort with noble men, and to please them!" (v.96). It is, however, a petition to the god, not only for the well-being of the narrator, but, most important, for the victor; that he may continue to evince himself as an $\alpha \gamma \alpha \dot{\phi} \dot{s} \alpha \dot{\alpha} \eta \dot{\rho} \rho$

\section{III}

It is thus clear from the aforesaid that verses $72-96$ contain specific instructions of the narrator to the laudandus on how to fulfil his role as victor in the games. These precepts, however, are so generally phrased that they equally apply to the narrator, and, for that matter, to the hearer as well. The principal opposition in verses 72-96 is between the narrator/victor, who present themselves as the Straightforward Ones, and the Deceiver.

Verses 72-74 expound the idea that human prosperity is inextricably linked to man's selfknowledge in respect to the limits of his mortal existence. To strive for what is beyond these limits amounts to self-deception. In verses 76-80 and 81-88 the narrator amplifies the nature of the deceiver. The deceiver, firstly, engages in "whispering" while steering clear of unreserved praise (vv.76-80), and, secondly, fails to recognise the duties imposed on men by the particular circumstances ( $v$. 81-88). The narrator, realising that the failure of the deceiver only leads towards self-destruction (verse 82), gratifies his xpéoৎ towards his patron (vv.83-85).

The last subsection, verses 88-96, recalls and extends the theme expounded in verse 72: knowledge of the limits imposed on men by our mortal existence is not sufficient; man should also recognise the governance of the god in the cosmos. However, verses 88-96 complete, thematically, a ring composition introduced by verse 2 in embryonic form, when the narrator pointed out that the god Ares was instrumental in establishing the glory of Syracuse.

Verses 88-96, in my view, touch upon the main theme of Pythian 2: human prosperity is inconceivable without the assistance of the god. Within this theme verses $72 \mathrm{ff}$. provide a necessary corollary: prosperity is equally inconceivable without knowledge of oneself.

\section{BIBLIOGRAPHY}

Adkins, A.W.H. [1960] 1975. Merit and Responsibility: A Study in Greek Values. Reprint. Chicago: University of Chicago Press.

Bakhtin, M. 1984. Problems in Dostoevsky's Poetics (trans. by Emerson, C.). Manchester: Manchester University Press.

Barthes, R. 1977. Music-Image-Text. London: Fontana Press.

Bowra, C.M. 1937. "Pindar Pythian ii." Hellenic Studies in Classical Philology 48, 1-28.

23 Verses 91 and 92 contain two images respectively, that of the measuring line $(\sigma \tau \dot{\alpha} \theta \mu \eta)$ which is drawn too tight, and of the sword or spear with which the envious destroy themselves (Carey 1981:60-1). 
Bowra, C.M. 1964. Pindar. Oxford: Clarendon Press.

Burtou, R.W.B. 1962. Pindar's Pythian Odes. Oxford: Oxford University Press.

Carey, C. 1981. A Commentary on Five Odes of Pindar. New Hampshire: The Ayer Company.

Farnell, L.R. 1932. The Works of Pindar. London: Macmillan.

Frãenkel, H. 1975. Early Greek Poetry and Philosophy (trans. by Hadas, M. and J. Willis). Oxford: Oxford University Press.

Genette, G. 1980. Narrative Discourse (trans., Lewin, J.E.). Ithaca: Cornell University Press.

Gerber, D.E. 1960. "Pindar Pythian 2.56." Transactions of the American Philological Assosiation 91, 100-108.

Gildersleeve, B.L. [1885] 1979. Pindar: The Olympian and Pythian Odes. Reprint. Atlanta: Scholarly Press.

Grimm, R.E. 1962. "Pindar and the Beast." Classical Philology 57, 1-9.

Lefkowitz, M.R. 1976. The Victory Ode: An Introduction. New Jersey: Noyes Press.

Lloyd-Jones, H. 1973. "Modern Interpretation of Pindar: The Second Pythian and Seventh Nemean Odes." Journal of Hellenic Studies 93, 109-137.

Louw, J.R. 1985. Pindaros se Tweede Puthiese Ode: 'n Literêre Ancilise. Unpublished M.A. thesis, University of Pretoria, Pretoria.

Most, G.W. 1985. The Measures of Praise: Structure and Function in Pindar's Second Pythian and Seventh Nemean Odes. Göttingen: Vandenhoeck \& Ruprecht.

Mullen, W. 1982. Choreia: Pindar and Dance. Princeton: Princeton University Press.

Oats, J.F. 1963. "Pindar's Second Pythian Ode." American Journal of Philology 84, 377389.

Prince, G. 1976. Narratology. The Form and Function of Narrative. The Hague: Mouton.

Propp, V. 1968. Morphology of the Folk-tale. Austin: University of Texas Press.

Rankin, H.D. 1975. "Archilochus in Pindar's Pythian 2." Emerita 43, 249-255.

Rubin, N.F. 1984. "The Epinician Speaker in Pindar's First Olympian: Toward a Model for Analyzing Character in Ancient Choral Lyric." Poetics 5(2), 377-397.

Thummer, E. 1972. "Die zweite pythische Ode Pindars." Rheinisches Museum fur Philologie 115, 293-307.

Woodbury, L. 1945. "The Epilogue of Pindar's Second Pythian." Transactions of the American Philological Association 76, 11-30. 